VALADARES, RN; NÓBREGA, DA; LIMA, LB; SILVA, JAS; SANTOS, AMM; MELO, RA; MENEZES, D. 2019. Combining capacity and heterosis in eggplant hybrids under high temperatures. Horticultura Brasileira 37: 348-353. DOI - http://dx.doi.org/10.1590/S0102-053620190315

\title{
Combining capacity and heterosis in eggplant hybrids under high temperatures
}

\author{
Ricardo de N Valadares ${ }^{1} \mathbb{D}$; Danieli A Nóbrega ${ }^{1} \mathbb{D}$; Lilian B de Lima ${ }^{1} \mathbb{D}$; Jordana Antônia dos S Silva ${ }^{1} \mathbb{D}$; \\ Ana Maria $M$ dos Santos ${ }^{1} \mathbb{D}$; Roberto de A Melo ${ }^{1} \mathbb{D}$; Dimas Menezes ${ }^{1} \mathbb{D}$
}

${ }^{1}$ Universidade Federal Rural de Pernambuco (UFRPE), Recife-PE, Brasil; rnvaladares@yahoo.com.br (corresponding author); dany.an@ hotmail.com.br; lilianbonfim53@gmail.com; jord.antonia@hotmail.com; agrom1960@yahoo.com.br; robertoagronomo@yahoo.com.br; dimasmenezes@superig.com.br

\begin{abstract}
The objective of this work was to estimate the combinatorial capacity and heterosis of eggplant hybrids under high temperature conditions. Seven genitors, twelve hybrid combinations, originated from a partial diallel, and the Ciça F1 hybrid, as control, were evaluated. The experiment was conducted under greenhouse conditions in randomized block design with four replications, from April to December 2017. The assessed traits related to high temperatures were pollen viability (PV) and fruit fixation index (FFI); the morphoagronomic traits were number of fruits per plant (NFP), fruit weight (FWe), production per plant (PP), fruit length (FL), fruit width (FWi), fruit length/width ratio (FLWR) and plant height $(\mathrm{PH})$. The variance analysis showed greater participation of the additive gene effects in relation to the non-additive gene effects in most traits, except for PV. The genitors CNPH 141, CNPH 135, CNPH 109 and CNPH 51 stood out with favorable gene effects to obtain genotypes tolerant to high temperatures, since they present good general combining ability (GCA) for the traits FFI, NFP and PP. The $1 \times 4$ and $3 \times 4$ hybrids presented positive estimates for both GCA and specific combining ability (SCA), demonstrating a greater potential to be used in breeding to increase the FFI, NFP and PP, under high temperatures. The $1 \times 4,1 \times 5$ and $1 \times 6$ hybrids expressed positive heterosis for most analyzed traits. The $1 \times 4$ hybrid stood out for the highest averages for PV, FFI, NFP and PP. For FWe, FL, FWi and FLWR, both positive and negative heterosis were observed, as consequence of the phenotypic variability of the genitors for these traits and suggests the possibility of selection for different sizes and formats.
\end{abstract}

Keywords: Solanum melongena, partial diallel, fixation index of fruits, pollen viability, productivity.

\section{RESUMO}

Capacidade combinatória e heterose em híbridos de berinjela sob altas temperaturas

Este trabalho teve como objetivo estimar a capacidade combinatória e a heterose de híbridos de berinjela em condições de altas temperaturas. Foram avaliados sete genitores, doze combinações híbridas oriundas de um dialelo parcial e o híbrido Ciça F1 como testemunha. O experimento foi conduzido em casa de vegetação, no delineamento experimental de blocos ao acaso com quatro repetições, de abril a dezembro de 2017. Foram avaliados os caracteres relacionados a altas temperaturas: viabilidade polínica (PV) e índice de pegamento de frutos (FFI) e os caracteres morfoagronômicos: número de frutos por planta (NFP), peso do fruto (FWe), produção por planta (PP), comprimento do fruto (FL), largura do fruto (FWi), relação comprimento/largura do fruto (FLWR) e a altura da planta (PH). Os resultados da análise de variância evidenciaram maior importância dos efeitos gênicos aditivos em relação aos efeitos gênicos não-aditivos na maior parte dos caracteres, exceto para PV. Os genitores CNPH 141, CNPH 135, CNPH 109 e CNPH 51 destacaram-se com efeitos gênicos favoráveis para obtenção de genótipos tolerantes a altas temperaturas, por apresentar boa capacidade geral de combinação (CGC) para os caracteres FFI, NFP e PP. Os híbridos 1x4 e $3 \times 4$ apresentaram estimativas positivas tanto para $\mathrm{CGC}$, quanto para capacidade específica de combinação (CEC), demonstrando maior potencial de uso em cruzamentos para incremento do FFI, NFP e PP, sob altas temperaturas. Os híbridos 1x4, 1x5 e 1x6 expressaram heterose positiva para a maioria dos caracteres analisados. $O$ híbrido 1x4 destacou-se com as maiores médias para PV, FFI, NFP e PP. Para o FWe, FL, FWi e FLWR observou-se tanto heterose positiva quanto negativa, consequência da variabilidade fenotípica dos genitores para esses caracteres, o que sugere possibilidade de seleção para diferentes tamanhos e formatos.

Palavras-chave: Solanum melongena, dialelo parcial, pegamento de frutos, viabilidade polínica, produtividade.

Received on August 8, 2018; accepted on May 7, 2019

$\mathrm{E}$ ggplant (Solanum melongena) is a vegetable from Solanaceae family and one of the few Solanum species from the Old World. In Brazil, it was introduced in the $16^{\text {th }}$ century by
Portuguese settlers and included in the diet of Brazilians by the Arabs (Boiteux et al., 2016; Ribeiro et al., 1998).

The area planted with eggplant in Brazil is around 1550 ha/year concentrated mainly in the CenterSouth region of the country. The fruits include a great diversity of shapes and colors, usually bright, which leads to its cultivation as an ornamental 
plant, besides cultivation as vegetable (Nascimento \& Freitas, 2014). The most common varietal group in the country is the purple-skinned and oblong-shaped group (Boiteux et al., 2016).

Eggplant is one of the most demanding vegetables for high temperature, with high sensitivity to cold and frost, during flowering and fruiting it tolerates milder temperatures (Polverente et al., 2005). The ideal temperature for crop growth and development is between 22 and $30^{\circ} \mathrm{C}$, the decrease to $17^{\circ} \mathrm{C}$ results in inhibition of plant development (Adamczewska-Sowińska \& Krygier, 2013). Flower abortion is favored by the natural reduction of daylight and high temperature at night $\left(30^{\circ} \mathrm{C}\right)$ (Saito \& Ito, 1973). Productivity is drastically reduced when temperature exceeds $32^{\circ} \mathrm{C}$ (Baswana et al., 2006).

In northeastern Brazil, especially when flowering coincides with the hottest period of the year, high temperatures have been a limiting factor for productivity, increasing the occurrence of malformation and/or fruit abortion, especially on crops under greenhouse conditions, where internal temperatures are higher than the outside one, causing a considerable reduction on crop yield in the region (Valadares et al., 2019). It is therefore important that high temperature tolerant eggplant strains and hybrids are obtained and evaluated under such conditions.

Eggplant hybrids can be obtained from crossbreeding involving malesterile strains or by manual emasculation and pollination (George, 2009). In the crossing stage, it is of fundamental importance to obtain information about combinatorial capacity, the per se potential of the strains, and estimates of heterosis of the hybrid combinations obtained, in order to discriminate superior genitors for hybridization in a breeding program. To meet this purpose, diallel crosses are used, whose analyzes allow estimating the general and specific combining ability (Griffing, 1956), making inferences about heterosis (Gardner \& Eberhart, 1966) and studying the genetic control of evaluated characters (Hayman, 1954).

There are also modifications adapted to partial diallels, such as Geraldi \&
Miranda Filho (1988) and Miranda Filho \& Geraldi (1984), adapted from Griffing (1956) and Gardner \& Eberhart (1966), respectively. Partial diallels were developed to increase the number of parents included in diallel crosses (Kempthorne \& Curnow, 1961; Hallauer et al., 2010) and have provided information on the presence and magnitude of additive, non-additive and heterosis gene effects, without the need of crossings between all parents (Cruz et al., 2012).

The present work aimed to estimate the combining ability (general and specific) and heterosis manifested in experimental hybrids obtained from diallel crosses between groups of eggplant lineages with agronomic potential, under high temperature conditions, in order to identify promising combinations for the selection of superior genotypes or that are competitive with the currently available hybrid cultivars.

\section{MATERIAL AND METHODS}

The experiment was conducted on Universidade Federal Rural de Pernambuco (UFRPE), Recife, Pernambuco, from April to December 2017.

In order to obtain F1 hybrids, 7 parents from the Embrapa Hortaliças Eggplant Germplasm Bank and previously selected (Valadares et al., 2019) were crossed in a $3 \times 4$ partial diallel arrangement, totaling twelve hybrid combinations.

The parents were stratified into two groups. Group 1 consisted of the genitors CNPH 135, CNPH109 and CNPH 47 and group 2 consisted of the genitors CNPH 141, CNPH 60, CNPH 53 and CNPH 51. Crosses were performed manually, emasculating flowers of the female genitors (group 2) and proceeding to pollination with pollen extracted from male genitors (group 1). Before and after crosses, measures were taken to ensure the genetic identity of each cross.

The plants were cultivated in open hydroponic system with substrate in a greenhouse. Mineral nutrition and water requirement were supplied by balanced nutrient solution at each stage of plant development, by $2 \mathrm{~L} \mathrm{~h}^{-1}$ drip irrigation system, automatically controlled by a digital timer, with irrigation amounts and duration adjusted according to weather conditions in the region and amount of nutrient solution absorbed daily by the plants.

The experimental design was a complete randomized block with 20 treatments (genotypes), twelve hybrid combinations obtained by partial diallel $3 \times 4$, seven genitors' lineages and one hybrid Ciça F1 as control and four replications.

The plots consisted of four pots filled with substrate (coconut powder) containing one plant each, spacing 1.75 $\mathrm{m}$ between rows and $0.60 \mathrm{~m}$ between plants.

We evaluated traits related to high temperatures: pollen viability (PV) and fruit fixation index (FFI); and other morphoagronomic traits: number of fruits per plant (NFP), fruit weight (FWe), production per plant (PP), fruit length (FL), fruit width (FWi), fruit length/width ratio (FLWR) and plant height (PH).

The average data of each trait was subjected to analysis of variance $(p<0.01)$ and averages grouped by ScottKnott procedure $(\mathrm{p}<0.01)$. To obtain general (GCA) and specific (SCA) ability estimates, the F1's genitors and hybrids averages were submitted to diallel analysis according to the partial diallel model proposed by Geraldi \& Miranda Filho (1988), adapted from the model 2 proposed by Griffing (1956). Estimates of heterosis relative to the parental averages were obtained for all hybrid combinations by the equation $\mathrm{Hr}=[\overline{\mathrm{F}} 1 /(\overline{\mathrm{P}} 1+\overline{\mathrm{P}} 2 / 2) \times 100]$ for each $\mathrm{F} 1$ hybrid combination. Analyzes were performed using the GENES program version 1990.2018.75.

\section{RESULTS AND DISCUSSION}

The micrometeorological data obtained during the experiment period showed that the maximum air temperature in greenhouse ranged between 38.2 and $52.5^{\circ} \mathrm{C}$ and the minimum temperature between 19.6 
and $24.9^{\circ} \mathrm{C}$. The average temperature ranged from 27.8 to $33.5^{\circ} \mathrm{C}$. Thus, the environment was classified as high temperature for eggplant cultivation. Relative humidity ranged from 65 to $79 \%$.

Decomposing the effects of treatments (genotypes) on general combining ability (GCA) and specific combining ability (SCA), significant differences for GCA were observed between group I and group II parents for most traits, except for pollen viability (PV). This indicates that the parents of groups I and II are heterogeneous and that the action of additive gene effects was able to influence the expression of the traits (Table 1).

The effects of SCA were significant for most traits except fruit length (FL) and fruit width (FWi). Thus, except these two characters, non-additive gene effects act and were important in the genetic control of traits. However, the upper squared averages of the GCA indicate that additive gene effects were more important in trait genetic control, except for PV, for which the nonadditive effect was higher (MSSCA>MSGCA) (Table 1).

In group I, only genitors $\mathrm{CNPH}$ 135 and CNPH 109 had positive GCA estimates for fruit fixation index (FFI), number of fruits per plant (NFP) and production per plant (PP), although negative for $\mathrm{PV}$ and fruit weight (FWe). In group II, genitor CNPH 51 stood out with positive GCA for most traits, except for FWe and FWi. High estimates of GCA, whether positive or negative, indicate that the genitor is better or worse than the others with respect to the average behavior of crosses (Griffing, 1956) and is preferred to constitute new populations (Miranda Filho et al., 1988).

The genitors' GCA estimates were both positive and negative for fruit weight (FWe). The genitors CNPH 47,

Table 1. Summary of variance analysis and estimates of general and specific combining ability of seven genitors in $3 \times 4$ partial diallel crosses, relative to nine traits of eggplant grown under high temperatures. Recife, UFRPE, 2017.

\begin{tabular}{|c|c|c|c|c|c|c|c|c|c|}
\hline Traits $^{1}$ & PV (\%) & FFI (\%) & NFP & PP (g) & FWe (g) & FL (cm) & FWi (cm) & FLWR & PH (m) \\
\hline & \multicolumn{9}{|c|}{ GCA (Group 1) } \\
\hline CNPH 135 (1) & -0.40 & 2.55 & 2.41 & 332.80 & -4.78 & -1.30 & 0.21 & -0.23 & -0.09 \\
\hline CNPH 47 (2) & 2.76 & -2.07 & -2.93 & -429.46 & 10.17 & 0.29 & 0.23 & -0.04 & 0.08 \\
\hline \multirow[t]{2}{*}{ CNPH 109 (3) } & -2.35 & 0.47 & 0.52 & 96.66 & -5.38 & 1.01 & -0.44 & 0.28 & 0.01 \\
\hline & \multicolumn{9}{|c|}{ GCA (Group 2) } \\
\hline CNPH 51 (4) & 3.63 & 2.82 & 3.26 & 331.45 & -18.33 & 1.45 & -0.91 & 0.60 & 0.05 \\
\hline CNPH 60 (5) & -0.26 & -1.76 & -1.50 & 70.42 & 30.96 & 0.54 & 0.34 & -0.08 & 0.09 \\
\hline CNPH 53 (6) & 0.91 & -5.26 & -4.01 & -432.25 & 15.95 & -0.42 & 0.96 & -0.35 & -0.01 \\
\hline \multirow[t]{2}{*}{ CNPH $141(7)$} & -4.28 & 4.20 & 2.25 & 30.36 & -28.58 & -1.15 & -0.39 & -0.16 & -0.13 \\
\hline & \multicolumn{9}{|c|}{ SCA } \\
\hline $1 \times 4$ & 12.11 & 13.80 & 9.33 & 676.84 & -28.71 & -0.33 & -0.70 & 0.10 & 0.07 \\
\hline $1 \times 5$ & -4.90 & 0.00 & 1.79 & 413.06 & -5.18 & -0.20 & -0.03 & -0.02 & 0.05 \\
\hline $1 \times 6$ & 31.16 & 0.64 & -0.69 & 318.31 & 11.79 & 0.67 & -0.00 & 0.07 & 0.06 \\
\hline $1 \times 7$ & -6.67 & 1.65 & 2.41 & 318.43 & -3.02 & 0.33 & 0.05 & 0.01 & 0.16 \\
\hline $2 \times 4$ & 1.81 & -1.89 & -0.63 & -38.20 & -13.15 & -0.26 & 0.44 & -0.32 & 0.09 \\
\hline $2 \times 5$ & 0.86 & 7.24 & 2.07 & 431.95 & -2.13 & 1.36 & 0.15 & 0.16 & 0.00 \\
\hline $2 \times 6$ & -16.87 & -3.10 & -0.84 & -221.05 & 47.02 & 0.15 & 0.08 & 0.00 & 0.09 \\
\hline $2 \times 7$ & -1.09 & -4.63 & -2.62 & -297.74 & -21.36 & 0.50 & -0.29 & 0.18 & 0.00 \\
\hline $3 \times 4$ & -11.90 & 2.34 & 0.85 & 389.72 & 17.38 & 0.48 & 0.32 & -0.07 & -0.16 \\
\hline $3 \times 5$ & -1.74 & -0.14 & 2.74 & 488.57 & -7.33 & 0.62 & -0.11 & 0.13 & -0.07 \\
\hline $3 \times 6$ & -0.18 & 1.58 & 1.07 & -9.37 & -15.78 & -0.40 & -0.38 & -0.02 & 0.11 \\
\hline $3 \times 7$ & -3.23 & 1.26 & -2.51 & -199.18 & 27.30 & -0.22 & 0.10 & -0.04 & -0.09 \\
\hline \multicolumn{10}{|c|}{ Mean square from the analysis of variance } \\
\hline$\overline{\mathrm{MS}_{\mathrm{GEN}}}$ & $543.97 * *$ & $203.30 * *$ & $124.65^{* *}$ & $1,772,648.98^{* *}$ & $5,963.16^{* *}$ & $14.38^{* *}$ & $4.06^{* *}$ & $1.18^{* *}$ & $0.13 * *$ \\
\hline MS $_{\text {GROUPS }}$ & $39.84^{\mathrm{NS}}$ & $13.88^{\mathrm{NS}}$ & $1.87^{\mathrm{NS}}$ & $1,019,237.18^{*}$ & $11,437.15^{* *}$ & $4.95^{\mathrm{NS}}$ & $1.11^{\mathrm{NS}}$ & $0.97 * *$ & $0.27 * *$ \\
\hline $\mathrm{MS}_{\mathrm{GCA}(1)}$ & $213.22^{\mathrm{NS}}$ & $176.49 * *$ & $234.94 * *$ & $4,872,690.04 * *$ & $2,485.72 *$ & $45.36^{* *}$ & $4.80 * *$ & $2.23 * *$ & $0.26^{* *}$ \\
\hline $\mathrm{MS}_{\mathrm{GCA}(2)}$ & $303.25^{\mathrm{NS}}$ & $527.46^{* *}$ & $318.91 * *$ & $2,824,165.37 * *$ & $22,087.91 * *$ & $46.99 * *$ & $19.14 * *$ & $4.96 * *$ & $0.27 * *$ \\
\hline $\mathrm{MS}_{\mathrm{SCA} 1 \times 2}$ & $701.29 * *$ & $142.51 * *$ & $67.94 * *$ & $1,055,880.69 * *$ & $2,055.39 * *$ & $1.85^{\mathrm{NS}}$ & $0.42^{\mathrm{NS}}$ & $0.08 * *$ & $0.06^{* *}$ \\
\hline
\end{tabular}

$\mathrm{PV}=$ pollen viability, $\mathrm{FFI}=$ fruit fixation index, $\mathrm{NFP}=$ number of fruits per plant, $\mathrm{PP}=$ production per plant, $\mathrm{Few}=$ fruit $\mathrm{weight}, \mathrm{FL}=$ fruit length,

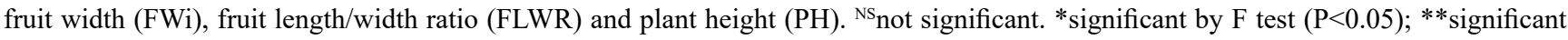
by $\mathrm{F}$ test $(\mathrm{P}<0.01)$. 
CNPH 53 and CNPH 60 had favorable additive effects for $\mathrm{FWe}$ and unfavorable for FFI and NFP traits (Table 1). This result indicates that selection for FFI and NFP only, which is important from a high temperature tolerance point of view, must meet a physiological limit of the plant, so that the adoption of only genitors with additive gene effects for these traits do not cause undesirable reduction in $\mathrm{FWe}$ due to negative correlation between FWe x FFI, NFP and PP (Valadares et al., 2019).

Positive and/or negative estimates of GCA were observed in parents for FL, FWi, FLWR and PH (Table 1). The genitors CNPH 135 and CNPH 53 showed favorable additive gene effects for FWi and unfavorable for FL and FLWR. On the other hand, genitors CNPH 109 and CNPH 51 showed favorable additive genetic effects for FL and fruit length/width ratio (FLWR) and unfavorable for FWi.
The genitors CNPH 47 and CNPH 60 had favorable additive gene effects for FL, FWi and unfavorable for FLWR (Table 1). These results are important because they indicate that the parents have both favorable and unfavorable effects for these traits and can be used in crossings aiming at different fruit shapes and sizes.

Only the genitor CNPH 141 presented negative values for the characters FWe, FL, FWi and FLWR indicating that its use in crossings will not result in superior progenies (Table 1). When GCA is high and negative, it demonstrates that a given genitor is inferior to the other diallel parents (Cruz et al., 2012).

Positive and/or negative GCA estimates were observed for plant height $(\mathrm{PH})$. In this case, most genitors had estimates close to zero (Table 1). Estimates of near-zero GCA indicate that the genitor does not differ from the overall average of crossings (Griffing, 1956).

Regarding the effects of SCA, the $1 \times 4,1 \times 7$ and $2 \times 5$ hybrids showed nonadditive gene effects for FFI, NFP and PP, although negative for FWe, due to the negative genetic correlation between FWe and the other traits (Valadares et al., 2019) (Table 1).

Among these, the $2 \times 5$ hybrid also presented positive SCA for PV, FL, FWi and FLWR. The best hybrid combinations have high SCA effects, positive or negative, and crosses should occur between divergent genitors, in which at least one of them has high GCA (Griffing, 1956; Cruz \& Vencovsky, 1989). The $1 \times 4$ and $3 \times 4$ hybrids showed positive estimates for both GCA and SCA for FFI, NFP and PP, showing higher potential for crossbreeding to obtain genotypes with high fruit fixation under high temperatures (Table 1).

For FL, FWi and FLWR, the

Table 2. Averages of the seven genitors, $12 \mathrm{~F}_{1}$ hybrids, and control, and relative heterosis $(\mathrm{Hr})$ to the genitors' average for four traits evaluated in eggplant under high temperatures. Recife, UFRPE, 2017.

\begin{tabular}{|c|c|c|c|c|c|c|c|c|}
\hline \multirow[t]{2}{*}{ Genotypes } & \multicolumn{2}{|c|}{ PV (\%) } & \multicolumn{2}{|c|}{ FFI (\%) } & \multicolumn{2}{|c|}{ NFP } & \multicolumn{2}{|c|}{ PP (g/plant) } \\
\hline & Average & $\mathbf{H}_{\mathrm{r}}$ & Average & $\mathbf{H}_{\mathrm{r}}$ & Average & $\mathbf{H}_{\mathrm{r}}$ & Average & $\mathbf{H}_{\mathrm{r}}$ \\
\hline CNPH 135 (1) & $24.00 \mathrm{~b}$ & - & $14.58 \mathrm{c}$ & - & $8.18 \mathrm{c}$ & - & $1,568.12 \mathrm{~b}$ & - \\
\hline CNPH 47 (2) & $53.83 \mathrm{a}$ & - & $14.60 \mathrm{c}$ & - & $4.93 \mathrm{c}$ & - & $969.43 \mathrm{c}$ & - \\
\hline CNPH 109 (3) & $44.50 \mathrm{a}$ & - & $14.07 \mathrm{c}$ & - & $9.75 \mathrm{c}$ & - & $1,624.31 \mathrm{~b}$ & - \\
\hline CNPH 51 (4) & $49.33 \mathrm{a}$ & - & $14.66 \mathrm{c}$ & - & $12.06 \mathrm{~b}$ & - & $1,531.56 \mathrm{~b}$ & - \\
\hline CNPH 60 (5) & $45.71 \mathrm{a}$ & - & $9.04 \mathrm{c}$ & - & $4.00 \mathrm{~d}$ & - & $856.87 \mathrm{c}$ & - \\
\hline CNPH 53 (6) & $37.83 \mathrm{~b}$ & - & $6.03 \mathrm{c}$ & - & $2.50 \mathrm{~d}$ & - & $474.37 \mathrm{c}$ & - \\
\hline CNPH 141 (7) & $40.00 \mathrm{~b}$ & - & $25.40 \mathrm{~b}$ & - & $16.18 \mathrm{~b}$ & - & $1,532.81 \mathrm{~b}$ & - \\
\hline $1 \times 4$ & $57.20 \mathrm{a}$ & 56.03 & $36.01 \mathrm{a}$ & 146.29 & $25.06 \mathrm{a}$ & 147.50 & $2,915.43 \mathrm{a}$ & 88.11 \\
\hline $1 \times 5$ & $36.29 \mathrm{~b}$ & 4.55 & $17.63 \mathrm{c}$ & 49.15 & $12.75 \mathrm{~b}$ & 109.18 & $2,390.62 \mathrm{a}$ & 97.16 \\
\hline $1 \times 6$ & $73.54 \mathrm{a}$ & 137.84 & $14.77 \mathrm{c}$ & 43.19 & $7.75 \mathrm{c}$ & 44.99 & $1,793.20 \mathrm{~b}$ & 75.58 \\
\hline $1 \times 7$ & $30.50 \mathrm{~b}$ & -4.68 & $25.25 \mathrm{~b}$ & 26.28 & $17.12 \mathrm{~b}$ & 40.52 & $2,255.93 \mathrm{a}$ & 45.50 \\
\hline $2 \times 4$ & $50.08 \mathrm{a}$ & -2.91 & $15.70 \mathrm{c}$ & 7.31 & $9.75 \mathrm{c}$ & 14.70 & $1,438.12 b$ & 15.00 \\
\hline $2 \times 5$ & $45.23 \mathrm{a}$ & -8.86 & $20.24 \mathrm{~b}$ & 71.16 & $7.68 \mathrm{c}$ & 72.03 & $1,647.25 \mathrm{~b}$ & 80.39 \\
\hline $2 \times 6$ & $28.66 \mathrm{~b}$ & -37.45 & $6.38 \mathrm{c}$ & -38.08 & $2.25 \mathrm{~d}$ & -39.51 & $491.56 \mathrm{c}$ & -31.90 \\
\hline $2 \times 7$ & $39.25 \mathrm{~b}$ & -16.34 & $14.33 \mathrm{c}$ & -28.35 & $6.75 \mathrm{c}$ & -36.11 & $877.50 \mathrm{c}$ & -29.86 \\
\hline $3 \times 4$ & $31.25 \mathrm{~b}$ & -33.39 & $21.53 \mathrm{~b}$ & 49.87 & $14.68 \mathrm{~b}$ & 34.70 & $2,392.18 \mathrm{a}$ & 51.60 \\
\hline $3 \times 5$ & $37.50 \mathrm{~b}$ & -16.59 & $14.44 \mathrm{c}$ & 25.00 & $11.81 \mathrm{~b}$ & 71.78 & $2,230.00 \mathrm{a}$ & 79.75 \\
\hline $3 \times 6$ & $40.25 \mathrm{~b}$ & -2.23 & $12.67 \mathrm{c}$ & 26.10 & $7.62 \mathrm{c}$ & 24.57 & $1,229.37 \mathrm{~b}$ & 17.15 \\
\hline $3 \times 7$ & $32.00 \mathrm{~b}$ & -24.26 & $21.83 \mathrm{~b}$ & 10.61 & $10.31 \mathrm{c}$ & -20.50 & $1,502.18 \mathrm{~b}$ & -4.83 \\
\hline Ciça $\mathrm{F}_{1}$ (control) & $15.63 \mathrm{~b}$ & - & $11.35 \mathrm{c}$ & - & $7.68 \mathrm{c}$ & - & $1,506.56 \mathrm{~b}$ & - \\
\hline
\end{tabular}

$\mathrm{PV}=$ pollen viability, $\mathrm{FFI}=$ fruit fixation index, $\mathrm{NFP}=$ number of fruits per plant, $\mathrm{PP}=$ production per plant. Averages followed by the same letters in the columns do not differ significantly from one another, Scott-Knott test (1\%). 
Table 3. Averages of seven genitors, $12 \mathrm{~F}_{1}$ hybrids, and control, and relative heterosis of genitors' average for five evaluated traits of eggplant under high temperatures. Recife, UFRPE, 2017.

\begin{tabular}{|c|c|c|c|c|c|c|c|c|c|c|}
\hline \multirow[t]{2}{*}{ Genotypes } & \multicolumn{2}{|c|}{ Fwe (g/plant) } & \multicolumn{2}{|c|}{ FL (cm) } & \multicolumn{2}{|c|}{ FWi (cm) } & \multicolumn{2}{|c|}{ FLWR } & \multicolumn{2}{|c|}{ PH (m) } \\
\hline & Average & $\mathbf{H}_{\mathrm{r}}$ & Average & $\mathbf{H}_{\mathrm{r}}$ & Average & $\mathbf{H}_{\mathrm{r}}$ & Average & $\mathbf{H}_{\mathrm{r}}$ & Average & $\mathbf{H}_{\mathrm{r}}$ \\
\hline CNPH 135 (1) & $191.91 \mathrm{a}$ & - & $12.02 \mathrm{~d}$ & - & $7.92 \mathrm{a}$ & - & $1.51 \mathrm{e}$ & - & $1.65 \mathrm{~b}$ & - \\
\hline CNPH 47 (2) & $204.08 \mathrm{a}$ & - & $14.57 \mathrm{c}$ & - & $7.41 \mathrm{a}$ & - & $1.96 \mathrm{e}$ & - & $2.11 \mathrm{a}$ & - \\
\hline CNPH 109 (3) & $167.37 \mathrm{~b}$ & - & $16.66 \mathrm{~b}$ & - & $6.29 \mathrm{~b}$ & - & $2.65 \mathrm{c}$ & - & $2.01 \mathrm{a}$ & - \\
\hline CNPH 51 (4) & $123.92 \mathrm{c}$ & - & $18.68 \mathrm{~b}$ & - & $4.89 \mathrm{~b}$ & - & $3.81 \mathrm{a}$ & - & $1.78 \mathrm{~b}$ & - \\
\hline CNPH 60 (5) & $217.60 \mathrm{a}$ & - & $15.91 \mathrm{c}$ & - & $7.43 \mathrm{a}$ & - & $2.14 \mathrm{~d}$ & - & $2.04 \mathrm{a}$ & - \\
\hline CNPH 53 (6) & $158.75 \mathrm{~b}$ & - & $14.65 \mathrm{c}$ & - & $8.83 \mathrm{a}$ & - & $1.71 \mathrm{e}$ & - & $1.68 \mathrm{~b}$ & - \\
\hline CNPH 141 (7) & $89.72 \mathrm{c}$ & - & $12.28 \mathrm{~d}$ & - & $6.02 \mathrm{~b}$ & - & $2.04 \mathrm{~d}$ & - & $1.53 \mathrm{~b}$ & - \\
\hline $1 \times 4$ & $116.79 \mathrm{c}$ & -26.03 & $15.1 \mathrm{c}$ & -1.69 & $5.55 \mathrm{~b}$ & -13.34 & $2.74 \mathrm{c}$ & 2.62 & $1.96 \mathrm{a}$ & 14.53 \\
\hline $1 \times 5$ & $189.63 \mathrm{a}$ & -7.38 & $14.32 \mathrm{c}$ & 2.54 & $7.47 \mathrm{a}$ & -2.60 & $1.91 \mathrm{e}$ & 4.91 & $1.99 \mathrm{a}$ & 7.56 \\
\hline $1 \times 6$ & $191.61 \mathrm{a}$ & 9.28 & $14.22 \mathrm{c}$ & 6.71 & $8.13 \mathrm{a}$ & -2.92 & $1.75 \mathrm{e}$ & 8.02 & $1.90 \mathrm{a}$ & 13.77 \\
\hline $1 \times 7$ & $132.24 \mathrm{c}$ & -6.09 & $12.76 \mathrm{~d}$ & 5.02 & $6.81 \mathrm{~b}$ & -2.15 & $1.87 \mathrm{e}$ & 5.61 & $1.88 \mathrm{a}$ & 17.50 \\
\hline $2 \times 4$ & $147.32 \mathrm{~b}$ & -10.17 & $16.76 \mathrm{~b}$ & 0.84 & $6.70 \mathrm{~b}$ & 9.01 & $2.50 \mathrm{c}$ & -13.64 & $2.16 \mathrm{a}$ & 11.56 \\
\hline $2 \times 5$ & $207.64 \mathrm{a}$ & -1.51 & $17.49 \mathrm{~b}$ & 14.72 & $7.69 \mathrm{a}$ & 3.49 & $2.29 \mathrm{~d}$ & 11.43 & $2.11 \mathrm{a}$ & 1.68 \\
\hline $2 \times 6$ & $241.79 \mathrm{a}$ & 33.28 & $15.30 \mathrm{c}$ & 4.75 & $8.24 \mathrm{a}$ & 1.41 & $1.87 \mathrm{e}$ & 1.35 & $2.09 \mathrm{a}$ & 10.81 \\
\hline $2 \times 7$ & $128.86 \mathrm{c}$ & -12.28 & $14.52 \mathrm{c}$ & 8.11 & $6.49 \mathrm{~b}$ & -3.42 & $2.23 \mathrm{~d}$ & 11.22 & $1.89 \mathrm{a}$ & 3.56 \\
\hline $3 \times 4$ & $162.29 \mathrm{~b}$ & 11.43 & $18.25 \mathrm{~b}$ & 3.25 & $5.90 \mathrm{~b}$ & 5.72 & $3.09 \mathrm{~b}$ & -4.48 & $2.17 \mathrm{a}$ & 14.73 \\
\hline $3 \times 5$ & $186.88 \mathrm{a}$ & -2.91 & $17.48 \mathrm{~b}$ & 7.30 & $6.73 \mathrm{~b}$ & -1.82 & $2.60 \mathrm{c}$ & 8.55 & $1.97 \mathrm{a}$ & -2.46 \\
\hline $3 \times 6$ & $163.43 \mathrm{~b}$ & 0.22 & $15.48 \mathrm{c}$ & -1.14 & $7.08 \mathrm{a}$ & -6.21 & $2.17 \mathrm{~d}$ & -0.68 & $2.05 \mathrm{a}$ & 11.35 \\
\hline $3 \times 7$ & $161.98 \mathrm{~b}$ & 26.00 & $14.52 \mathrm{c}$ & 0.31 & $6.20 \mathrm{~b}$ & 0.89 & $2.34 \mathrm{~d}$ & -0.21 & $1.72 \mathrm{~b}$ & -2.80 \\
\hline Ciça $\mathrm{F}_{1}$ (control) & $190.33 \mathrm{a}$ & - & $21.04 \mathrm{a}$ & - & $6.75 \mathrm{~b}$ & - & $3.12 \mathrm{~b}$ & - & $2.05 \mathrm{a}$ & - \\
\hline
\end{tabular}

$\mathrm{Fwe}=$ fruit weight, $\mathrm{FL}=$ fruit length, $\mathrm{FWi}=$ fruit width, $\mathrm{FLWR}=$ fruit length/width ratio, $\mathrm{PH}=$ plant height. Averages followed by same letters in the columns do not differ significantly from one another, Scott-Knott test (1\%).

estimates for SCA were positive for most hybrids (Table 1). For PH the SCA estimates were positive and/or negative, but close to zero, indicating that the performance of the hybrids occurred as expected in relation to their parents (Table 1).

The $1 \times 4,1 \times 5$ and $1 \times 6$ hybrids expressed positive heterosis for most traits analyzed (Table 2). Positive, as well as negative heterosis in eggplant hybrids are reported for these traits by several authors (Shafeeq et al., 2007; São \& Mehta, 2010; Dharwad et al., 2011; Singh et al., 2012, 2016; Kumar et al., 2013; Dubeyet et al., 2014; Reddy \& Patel, 2014; Magar et al., 2016; Sivakumar et al., 2017; Patel et al., 2017).

Overall hybrids had higher averages than parents for most characters (Table 2). However, only $1 \times 4$ hybrid stood out with the highest averages for PV, FFI, NFP and PP (Table 2). FFI is the trait most influenced by high temperatures in the Northeast Brazil, because under high temperatures it is drastically reduced, beside that it has a genetic correlation with the traits NFP and PP (Valadares et al., 2019).

Although the percentages of PV, FFI, NFP and PP were close to or below the values reported by other authors (Silva et al., 1999; Baswana et al., 2006; Valadares et al., 2019), the averages obtained for hybrids and genitors were superior to those obtained for Ciça in most traits, except for FWe, FL and PH, where Ciça stood out among the best genotypes (Table 3).

For FLWR, indicative of fruit shape, genitors and hybrids differed in the vast majority from the Ciça hybrid (Table $3)$. In this case, because genotypes with variation in fruit size and shape were used, the variability observed in the crosses indicates the possibility of selection of fruits with variations in shape and size, and not exclusively similar to the hybrid Ciça.

In addition, FLWR values should not be considered isolated to avoid misclassification of fruits, even if genotypes produce fruits with desired shape. It is therefore recommended that the FLWR values be analyzed in conjunction with FL and FWi values. So, for FWi, some hybrids and genitors did not differ from the commercial hybrid Ciça (Table 3), while for FL all differed from Ciça. Variation in FL and FWi have been reported by other authors (Sao \& Mehta, 2010; Singh et al., 2012; Kumar et al., 2013; Dubey et al., 2014; Sivakumar et al., 2017; Valadares et al., 2019).

Additive gene effects were more important than nonadditive ones for most analyzed traits, except for PV. Genitors CNPH 141, CNPH 135, CNPH 109 and CNPH 51 stood out with favorable gene effects to obtain high 
temperature tolerant genotypes, having good GCA for FFI, NFP and PP.

The $1 \times 4$ and $3 \times 4$ hybrids showed positive estimates for both GCA and SCA, showing higher potential for crossbreeding to increase FFI, NFP and PP under high temperatures.

The $1 \times 4,1 \times 5$ and $1 \times 6$ hybrids expressed positive heterosis for most analyzed traits.

The $1 \times 4$ hybrid stood out with the highest averages for PV, FFI, NFP and PP.

For FWe, FL, FWi and FLWR, both positive and negative heterosis were observed, as a consequence of the phenotypic variability of the genitors for these traits and suggests the possibility of selection for different fruit formats and sizes.

\section{ACKNOWLEDGMENTS}

To Capes for granting doctoral scholarship of the first author and to Embrapa Hortaliças for giving the accesses for this study.

\section{REFERENCES}

ADAMCZEWSKA-SOWIŃSKA, K; KRYGIER, M. 2013. Yield quantity and quality of field cultivated eggplant in relation to its cultivar and the degree of fruit maturity. Acta Scientiarum Polonorum-Hortorum Cultus 12: 13-23.

BASWANA, KS; DAHIYA, MS; KALLOO, NK; SHARMA, BS; DHANKHAR, BS; DUDI, BS. 2006. Brinjal HLB-25: A high temperature tolerant variety. Haryana Journal of Horticultural Sciences 35: 318-319.

BOITEUX, LS; MENDONÇA, LJ; FONSECA, MEN; REIS, A; VILELA, NJ; GONZÁLEZARCOS, M; NASCIMENTO, MN. 2016. Melhoramento de berinjela. In: NICK, C; BORÉM, A (eds). Melhoramento de Hortaliças. Viçosa: Editora UFV. p.15-192.

CRUZ, CD; REGAZZI, AJ; CARNEIRO, PCS. 2012. Modelos biométricos aplicados ao melhoramento genético. $4^{\mathrm{a}}$ ed. Viçosa: Editora UFV. $514 \mathrm{p}$.

CRUZ, CD; VENCOVSKY, R. 1989. Comparação de alguns métodos de análise dialélica. Revista Brasileira de Genética 12: 425-38.

DHARWAD, NA; PATIL, AS; SALIMATH, PM. 2011. Heterosis and combining ability analysis for productivity traits in brinjal (Solanum melong na L.). Karnataka Journal of Agricultural Sciences 24: 622-625.

DUBEY, R; DAS, A; OJHA, MD; SAHA, B; RANJAN, A; SINGH, PK. 2014. Heterosis and combining ability studies for yield and yield attributing traits in brinjal (Solanum melongena L.). The Bioscan 9: 889-894.

GARDNER, CO; EBERHART, SA. 1966. Analysis and interpretation of the variety cross diallel and related population . Biometrics 22: 439-452.

GEORGE, RAT. 2009. Vegetable seed production. London: CAB Publishing. 320p.

GERALDI, IO; MIRANDA FILHO, JB. 1988. Adapted models for the analysis of combining abilty of varieties in partial diallel crosses. Revista Brasileira de Genética 11: 419-30.

GRIFFING, B. 1956. Concept of general and specific combining ability in relation to diallel crossing systems. Australian Journal of Biological Sciences 9: 463-493.

HALLAUER, AR; CARENA, MJ; MIRANDA FILHO, JB. 2010. Quantitative genetics in maize breeding. $3^{\text {rd }}$ ed. Berlin: Springer Verlag. 500p.

HAYMAN, BI. 1954. The theory and analysis of diallel crosses. Genetics 39: 789- 809.

KEMPTHORNE, O; CURNOW, RN. 1961. The partial diallel cross. Biometrics 17: 50-229.

KUMAR, SR; ARUMUGAM, T; ANANDAKUMAR, CR; BALAKRISHNAN, S; RAJAVEL, DS. 2013. Heterosis expression, interrelationship, direct and indirect effects of component characters on yield in intervarietal crosses of eggplant. African Journal of Biotechnology 12: 6366-6375.

MAGAR, PG; MAGAR, VG; GAIKWAD, SS. 2016. Heterosis studies for growth and flowering characters in brinjal (Solanum melongena L.). International Journal of Tropical Agriculture 34: 2279-2281.

MIRANDA FILHO, JB; GERALDI, IO. 1984. An adapted model for the analysis of partial dialel crosses. Revista Brasileira de Genética 7: 677-88.

MIRANDA, JEC; COSTA, CP; CRUZ, CD. 1988. Análise dialélica em pimentão. I. Capacidade combinatória. Revista Brasileira de Genética 11: 431-440.

NASCIMENTO, WM; FREITAS, RA. 2014. Produção de sementes de berinjela. In Nascimento WM (ed). Produção de sementes de hortaliças II. Brasília: Embrapa. p.53-74.

PATEL, AA; GOHIL, DP; DHRUVE, JJ; DAMOR, HI. 2017. Heterosis for fruit yield and its quality characters in brinjal (Solanum melongena L.). Journal of Pharmacognosy and Phytochemistry 6: 975-978.

POLVERENTE, MR; FONTES, DC; CARDOSO, AII. 2005. Eggplant seed production and quality in different times of manual pollination. Bragantia 64: 467-472.

REDDY, EEP; PATEL, AI. 2014. Heterosis studies for yield and yield attributing characters in brinjal (Solanum Melongena L.). Journal of Recent Advances in Agriculture 2: 175-180.

RIBEIRO, CSC; BRUNE S; REIFSCHNEIDER, FJB. 1998. Cultivo da berinjela (Solanum melongena L.). Brasília: Embrapa. 24p. (Instruções Técnicas, 15).

SAITO, T; ITO, H. 1973. Studies on the flowering and fruiting in eggplant VIII. Effects of early environmental conditions and cultural treatments on the development and the drop of flowers. Journal of the Japanese Society for Horticultural Science 42: 155-162.

SAO, A; MEHTA, N. 2010. Heterosis in relation to combining ability for yield and quality attributes in Brinjal (Solanum melongena L.). Electronic Journal of Plant Breeding 1: 783-788.

SHAFEEQ, A; MADHUSUDAN, K; HANCHINAL, RR; VIJAYAKUMAR, AG; SALIMATH, PM. 2007. Heterosis in brinjal. Karnataka Journal of Agricultural Sciences 20: 33-40.

SILVA, DJH; COSTA, CP; CASALI, VWD; DIAS, LAS; CRUZ, CD.1999. Relação entre divergência genética de acessos de berinjela e desempenho de seus híbridos. Horticultura Brasileira 17: 129-133.

SINGH, AP; NAIK, MR; PRASAD, I; DAPKE, JS; PATEL, NM. 2016. Heterosis for fruit yield in diverse Brinjal (Solanum melongena L.) germplasm. International Journal of Applied and Pure Science and Agriculture 2: 211-215.

SINGH, K; SIDHU, AS; KUMAR, A. 2012. Heterosis for fruit yield and its components in brinjal (Solanum melongena L.). Journal of Horticultural Science 7: 142-144.

S I VA K UM A R, V; JY O T H I, KU; VENKATARAMANA, C; RAJYALAKSHMI, R. 2017. Estimation of heterosis for yield and yield components in brinjal (Solanum melongena L.) over locations. International Journal of Current Microbiology and Applied Sciences 6: 1074-1081.

VALADARES, RN; LIMA, LB; NÓBREGA, DA; SILVA, JAS; MENDES, AQ; COSTA, IJN; MENEZES, D. 2019. Pollen viability in eggplant using colorimetric and in vitro techniques. Journal of Experimental Agriculture International 32: 1-7.

VALADARES, RN; NÓBREGA, DA; MOREIRA, CS; SILVA, JAS; MENDES, AQ; SILVA, FS; COSTA, IJN; MENEZES, D. 2019. Selection of eggplant genotypes tolerant to high temperatures. Journal of Experimental Agriculture International 31: 1-10. 